\title{
Farklı Öğretim Kademelerindeki Öğrencilerin Deneme Türündeki Yazılı Anlatım Becerilerinin Değerlendirilmesi
}

\author{
DOI: 10.26466/opus.733517
}

*

\section{Serdar Derman *}

* Dr. Öğretim Üyesi, Necmettin Erbakan Üni.Ahmet Keleşoğlu Eğitim Fak, Konya/Türkiye E-Posta: serdarderman@gmail.com

ORCID: $\underline{0000-0001-6209-0249}$

\section{$\ddot{O} z$}

Dil becerileri anlama (dinleme-okuma) ve anlatma (konuşma-yazma) olmak üzere dört temel dil becerisinden oluşmaktadır. Bu dil becerileri arasında yazma öğretimi en son ve en zor gelişen dil becerisidir. Bu çalışmada ortaokul, lise ve üniversite düzeyindeki öğrencilerin deneme türünde kaleme aldıkla$r$ kompozisyonları aracılı̆̆ıyla yazılı anlatım becerilerinin değerlendirilmesi amaçlanmış̧ır. Bu araştırma ortaokul, lise ve üniversite (lisans) öğrencilerinin yazma becerilerini detaylı bir biç̧imde ele alması, ortaya çıkan yapılar içerisinde nedensel bağlantı olduğu varsayılan olayları açıklaması bakımından kesitsel bir durum çalışmasıdır. Bu araştırmanın katılımcıları İç Anadolu Bölgesi'nde yer alan bir devlet üniversitesinin eğitim fakültesinin farklı programlarında öğrenim gören 80 öğretmen adayı ile Konya il merkezindeki bir devlet lisesinin 12. sinifina devam eden 80 öğrenci ve Konya il merkezindeki bir devlet ortaokulunun 8. sinıfina devam eden 80 öğrenciden oluşmaktadır. Farklı öğretim düzeylerindeki öğrencilerin deneme türünde kaleme aldıkları kompozisyonlar bu araştırmanın veri kaynağını oluşturmuştur. Verilerin analizinde tematik içerik analizi kullanılmıştır. Öğrencilerin oluşturdukları metinleri değerlendirmek için dış yapı (biçim), dil ve anlatım (üslup), yazım ve noktalama özellikleri ile ilgili ölçütler içeren "değerlendirme cetveli" kullanılmıştır. Analizler sonucunda metnin dış yapısı unsurlarından kağıt düzeni; düzgün, okunaklı ve işlek bir yazı kullanma; konunun mantıksal tutarlılık ve bütünlük içinde anlatılması; paragraflar arası geçiş sağlayabilme; yazıda verilmek istenen temel iletiyi, duyguyu, anafikri işleme; anafikri yardımo fikirlerle destekleme; sonuç ifadesinin konuyu bağlayıcı ve etkileyici olmasl; kurallara uygun cümle kurma; kelimelerin yerinde ve doğru anlamda kullanılması; konuyu kendine özgü ifadelerle anlatabilme ölçütlerinde öğretim düzeylerine göre artan kademeli bir artış belirlenmiştir. Başlı̆̆ı konuyla ilişkilendirme, cümlede gereksiz sözcük tekrarı yapılmamasl, yazım kurallarına uyulması, noktalama işaretlerini doğru yerde kullanma ölçütlerinde öğretim düzeylerine göre dengeli bir artış olmadığı tespit edilmiştir. Elde edilen bulgular ilgili çalışmalarla karşılaştırılarak öğretime yönelik bazı çıkarımlarda bulunulmuştur.

Anahtar Kelimeler: Deneme yazma, yazılı anlatım, farklı öğretim kademeleri, içerik analizi 


\title{
Evaluation of Written Expression Skills of Experiment Type of Students in Different Teaching Levels
}

\begin{abstract}
Language skills consist of four basic language skills: understanding (listening-reading) and telling (speaking-writing). Among these language skills, teaching writing is the latest and most difficult developing language skill. The aim of this study is to evaluate the written expression skills of middle school, high school and university level students through essays written in the essay type. This research is a cross-sectional case study in which middle school, high school and university (undergraduate) students take a detailed account of their writing skill. The participants of this study were 80 teachers from different programs of the Faculty of education of a State University in the Central Anatolia region and 12 from a state High School in the central Konya province. 80 students attending class and 8 of a state secondary school in the city center of Konya. It consists of 80 students who attend its class. The essays written by students at different levels of education in the essay type formed the data source of this research. Thematic content analysis was used in the analysis of the data. In order to evaluate the texts the students created, an "evaluation chart" containing criteria related to external structure (form), language and expression (style), spelling and punctuation were used. As a result of the analysis, a gradual increase in criteria such as paper layout, using a smooth, legible and busy writing, explaining the subject with logical consistency and integrity, being able to pass between paragraphs, processing the basic message, feeling, anaphicry, supporting the subject with helpful ideas, making the result statement binding and expressive, making sentences according to the rules, using the words in a proper and correct sense was determined by different levels of teaching. It was determined that there was no balanced increase in the criteria such as associating the title with the subject, not repeating unnecessary words in the sentence, following the spelling rules, using punctuation marks in the right place. The findings were compared with the related studies and some inferences were made about teaching.
\end{abstract}

Keywords: Essay writing, written expression, different levels of teaching, content analysis 


\section{Giriş}

Türkçe öğretiminin etkinlik alanları, Türkçenin dört temel becerisinin öğrencilere kazandırılması ilkesinden hareketle ortaya konulmuştur. Böylece bu temel beceriler olan anlama (okuma, dinleme) ve anlatım (konuşma, yazma) Türkçenin temel becerileri olarak karşımıza çıar. Türkçe derslerinin temel hedefi, öğrenciye bu becerileri kazandırmaktır. Ana dili edinim süreci içerisinde örgün eğitimin başlamasıyla birlikte öğrenciler ilk olarak temel okuma ve yazma becerisini kazanırlar. Okuyup yazabilme yeteneğini kazanan öğrencilerin, öğretim süreci içerisinde Türkçenin dört temel becerisini kazanmalarını ve aşamalı olarak bu becerilerini daha güzel, daha doğru olarak kullanmalarını sağlamak hedeflenir (Derman, 2008, s.1).

\section{Problem Durumu}

Yazma becerisinin öğretimi, okullarda, ilk olarak okuma becerisinin kazandırılmasıyla başlayan süreci takip etmektedir. Bu süreç çocuğun harflerden önce resim ve şekilleri çizmesi, gördügü kelime ve heceleri taklit etmesi ve son olarak harfleri yazması sürecine kadar devam etmektedir. Okuma yazma aşamasını tamamlayan öğrencilerin bundan sonraki süreçte akıcı olarak okuması ve seri olarak yazması hedeflenmektedir (Güneş, 2013, s.166-167).

Yazmak, duyduklarımızı, düşündüklerimizi, tasarladıklarımızı, görüp yaşadıklarımızı yazı ile anlatmaktır. Konuşma gibi, başkalarıyla iletişim kurmanın, kendimizi anlatmanın bir yoludur (Sever, 1995, s.22). Kompozisyon ya da yazı, birbiriyle ilgili paragrafların bir başlık altında oluşturduğu bütündür. Herhangi bir konuda duygu, hayal ya da özgün fikirleri belli bir düzen ve bütünlük içinde yazıya geçirme işine de yazma denir. (Göçer, 2010, s.178). Aktarılmak istenen anlamların sembollerle kodlanması" şeklinde tanımlayabileceğimiz yazı yani yazma becerisi en son olarak edinilen temel dil becerisidir (Karadağ ve Maden, 2014).

Yazılı anlatım, dilin kuralları dâhilinde dilin tüm inceliklerini içine alan bir süreci oluşturur. İnsanlar olayları söz ile anlatırken akıcı, sürükleyici, zevk uyandırıcı bir anlatım şekline büründürürken aynı olayı yazılı olarak anlatmaları istendiğinde daha çekimser, içe kapanık hatta konuyu geçiştiren tavırlar sergiledikleri görülmektedir. Bu tavrın sebebinin yazılı anlatımın 
zorlu bir süreç olmasından kaynaklandığı söylenebilir. (Yakıcl, Yücel ve diğerleri, 2011)

Etkili ve güzel yazı yazabilmekse başta iyi bir yazma eğitimi almaya ve bunu uygulayabilmeye bağlıdır. Bu gerçekten hareketle, öğrencilere çocukluktan başlayarak yazma eğitiminin verilmesi, yazılarının incelenmesi ve hatalarının ortaya çıkarılıp bunlara göre çalışmalar yapılması onların bu becerilerinin gelişmesine ve dolayısıyla iyi yazı yazabilmelerine katkı sağlayabilir. Yazma eğitiminin önemli bir kısmı ilköğretim döneminde verilmektedir (Arıcı ve Ungan, 2008).

Okullarımızda verilen yazma eğitiminin ulaşmak istediği nihai nokta, edebî değer taşıyan anlatma yeteneğinin öğrencilere kazandırılmasıdır. Bu ifadedeki amaç, öğrencilerin yazarlık seviyesinde eserler kaleme alması değildir. Yapılan araştırmalar göstermektedir ki iyi ve doğru yazmak, yazma zevk ve alışkanlığına sahip olmak, yazma yöntem ve tekniklerini bilmek, yazılı anlatımlarda dilbilgisi kurallarına uygun olarak yazmak sadece yetenekle sınırlı değildir; aynı zamanda yeterli bilgiyi edinmeye bağlı olarak da gelişmektedir (Karadağ ve Maden, 2014, s.271-272). Bu sebeple yazma becerisinin tüm öğretim kademelerinde birbirini takip eden ve tamamlayan bir anlayışla sadece bir ders etkinliği olmaktan ziyade hayatla iç içe ve hayata dönük iletişimsel bir eylem olarak düşünmek, tasarlamak ve yapılandırmak gerekir. Yazmak, sosyal bir varlık olan insanın düşünceye ve estetiğe bakan yüzünün en doğal, en etkili ve kalıc biçimde dışavurumudur. Öyleyse yazma öğretiminin bir yönü ilgi, tutum, heves ve heyecan gibi psikolojik unsurlara bağlıyken daha önce belirtildiği gibi bir yönü de bilgi ve tecrübe aktarımına dayalıdır.

Ülkemizde eğitim sisteminin bireylere istenilen ölçü ve niteliklerde bir yazma becerisi kazandırdığı söylenemez. Bu hususta yapılan akademik çalışmalarda belirtilen sorunlardan biri de öğretim kademelerinin birbirini destekleyemediğidir. Öğrencilerin yazılarının öğretimin ilerleyen kademelerinde aşamalı olarak derinleşmesi, dil kullanımı açısından doğru, kurallı ve etkili bir kullanımın yanında farklı dil yapılarını Türkçemizin dil zenginliğini yansıtacak bir biçimde bünyesinde barındırması beklenir.

Farklı öğretim kademelerine yönelik öğretim programlarında söz konusu bu ilkelere değinilmekte ancak bu ilkeler öğrencilerin yazma alanındaki akademik başarılarına aktarılamamakta ve öğrencilerden beklenen nitelikli yazılar elde edilememektedir. Bir önceki öğretim kademesindeki eksiklikle- 
rin bir sonraki öğretim kademesinde büyüyüerek devam etmesi yazma öğretimini sıradan, kısır ve sınırlı bir çerçevede sürdürülen bir etkinlik alanına dönüştürmektedir.

Alanyazında yazma becerisinin farklı unsurlarına yönelik sayı ve nitelik açısından oldukça verimli çalışmaların yapıldığı görülmektedir. Bu çalışmalardan belirli bir kısmı da farklı öğretim kademelerindeki öğrencilerin yazılarının değerlendirilmesine, bu değerlendirmelerden hareketle yazma ilkeleri çerçevesinde yapılan hataların belirlenmesine yöneliktir.

Yazma becerisinde hataların tespit edilmesi, düzenleyici, kavratıcı, gelişimsel geribildirim verme bakımından öğrenciler için ne kadar önemliyse öğretimin planlanması, düzenlenmesi, tamamlanması, eksikliklerin giderilmesi bakımından öğreticiler için de en azından o kadar değerlidir.

Yazılı anlatımla ilgili farklı öğretim kademelerine yönelik çalışmalarda, öğrenci yazılarından tespit edilen sorunlardan biri de öğrencilerin tek tip ve benzer konularda yazılar kaleme almaları, farklı temalarda ve farklı türlerde yazı yazmakta zorlanmalarıdır. Yaşamın getirdiği gereksinimler doğrultusunda öğrencilerin farklı türlerde metinler yazmayı öğrenmeleri son derece önemlidir. Bu metin türleri, edebi türler (deneme, hikâye, şiir, mektup vb.) olabileceği gibi, günlük yaşamın farklı alanlarında ortaya çıkan ihtiyaçlara yönelik metin türleri de (davetiye, broşür, reklam metni, kartvizit, ilan vb.) olabilir (Coşkun ve Tiryaki, 2013).

Bu çalışmada ortaokul, lise ve üniversite öğrencilerinin bilgilendirici metin türlerinden biri olan deneme türündeki yazılarının birlikte değerlendirilerek söz konusu öğretim kademelerinin genel durumu ve yapılan hata türleri belirlenmeye çalışılmıştır. Bilgilendirici metin oluşturma, ortaokul ve lise Türkçe/Türk dili ve edebiyatı öğretim programlarında üzerinde önemle durulan hususlardan biridir.

Ortaokul düzeyinde, Türkçe Öğretim Programı'nda 7 ve 8. sınıf düzeyindeki yazma kazanımlarında şu ifadeler yer almaktadır: "Bilgilendirici metin yazar. a) Öğrencilerin giriş, gelişme ve sonuç bölümlerinde yazacakların belirleyerek bir metin taslağı oluşturmaları, düşünceyi geliştirme yollarını kullanmaları, yazılı ve çoklu medya kaynaklarından görüşlerini destekleyecek kanıtlar sunmaları sağlanır. b) Öğrenciler günlük hayattan örnekler vermeye teşvik edilir (MEB, 2018a, s.46). Ayrıca programda yer alan "Yazdıklarının içeriğine uygun başlık belirler./Yazılarında uygun geçiş ve bağlantı ifadelerini kullanır./Yazdıklarını düzenler. a) Anlama dayalı anla- 
tım bozuklukları bakımından yazdıklarını gözden geçirmesi ve düzeltmesi sağlanır. b) Metinde yer alan yazım ve noktalama kuralları ile sınırlı tutulur." ifadelerine yönelik kategoriler veri değerlendirme cetvelinde yer almıştor.

Lise düzeyinde ise Ortaöğretim Türk Dili ve Edebiyatı Dersi Öğretim Programı'nda deneme türündeki yazma kazanımları 12. sınıfta “Öğrencilerden istedikleri bir konuda deneme yazmaları istenir./ Öğrencilerin yazd1ğ1 yazılar çeşitli araç ve yöntemlerle (sınıf panosu, okul panosu, dergi, gazete, sosyal medya...) sergilenir." şeklinde yer almaktadır (MEB,2018b, s.62).

Yine programda yer alan "Yazacağı metnin türüne göre konu, tema, ana düşünce, amaç ve hedef kitleyi belirler./ Yazacağı metni planlar./ Metin türüne özgü yapı özelliklerine uygun yazar. a. Metnin türüne göre birimlere, paragraflara, bölümlemelere, giriş-gelişme-sonuç/serim- düğümçözüm aşamalarına ve olay örgüsüne dikkat çekilir. b. Başlığı belirlemesi ve gerekirse alt başlık/bölüm başlığı ve epigraf kullanması sağlanır./ Metin türüne özgü dil ve anlatım özelliklerine uygun yazar./ Farklı cümle yapılarını ve türlerini kullanır./ Yazdığı metni dil bilgisi, yazım ve noktalama bakımından gözden geçirmesi sağlanır./ Birimler, paragraflar, bölümler, olay örgüsü/kurgu ve başlık gibi yapı ve şekil unsurları arasındaki anlam bağlantıları, tutarlılık, denge ve akış bakımından gözden geçirmesi sağlanır./ Yazısının okunaklılığını ve sayfa düzenini gözden geçirmesi sağlanır." ifadeleri dikkate alınarak veri değerlendirme cetveli gözden geçirilmiştir.

Türkçe Dersi Öğretim Programları (2006a, 2015, 2018a) ile Türk Türk Dili ve Edebiyatı/Dil ve Anlatım Dersi Öğretim Programları (2006b, 2018b) yazma amaç ve kazanımları bakımından Konya ili ortaokul 8. sınıf, lise 12. sınıf ve lisans 3. sınıfta öğrenim gören öğrencilerin yazılı anlatım becerileri karşılaştırıldığında ortaya nasıl bir durum çıkmaktadır?

\section{Alt Problemler}

1. Ortaokul düzeyindeki öğrencilerin yazılı anlatım becerileri hangi seviyededir?

2. Lise düzeyindeki öğrencilerin yazılı anlatım becerileri hangi seviyededir?

3. Lisans düzeyindeki öğrencilerin yazılı anlatım becerileri hangi seviyededir? 


\section{Araştırmanın Amacı}

$\mathrm{Bu}$ çalışmada ortaokul, lise ve lisans düzeyindeki öğrencilerin deneme türünde kaleme aldıkları kompozisyonları aracılığıyla yazılı anlatım becerilerinin değerlendirilmesi ve öğrencilerin yazılı anlatım becerilerinin karşılaştırılması amaçlanmıştır.

\section{Araştırmanın Önemi}

Türkçe öğretiminin dört temel becerisinden biri olan yazma becerisinin öğrencilere kazandırılması, ortaokul Türkçe öğretim programında, ortaöğretim Edebiyat dersi öğretim programında ve öğretmen yetiştirme programlarında önemli görülen ve geniş yer ayrılan önemli bir husustur.

“Türkçe Dersi Öğretim Programı'nda (MEB, 2006, 2015, 2018), “Ortaöğretim Türk Dili ve Edebiyatı Dersi Öğretim Programı'nda (MEB, 2018) ve “Dil ve Anlatım Dersi Öğretim Programı'nda (MEB, 2005, 2011) yazma becerisinin nitelikleri, öğretim şekli, öğrenciye kazandırılması hedeflenen kazanım ve alışkanlıklar, yazma becerisinin değerlendirilmesi gibi hususlar ayrıntılı bir biçimde ele alınmıştır.

Lisans öğrencilerinin de daha önceki öğretim basamaklarında edindikleri Türkçe dersine ait beceri ve alışkanlıklarını sürdürmeleri ön görülmüş ve lisans programlarının tamamında bu amaca hizmet etmek gayesiyle Türk Dili dersleri zorunlu ders olarak yer almıştır.

Öğretmen yetiştiren eğitim fakültelerinde yukarıda belirtilen hususun yanında güzel konuşma ve yazma becerisi, tüm disiplinlerde temel öğretmen yeterlilikleri çerçevesinde de önemli bir beceri alanı olarak görülmektedir. Örgün öğretimin farklı basamaklarında kazandırılması hedeflenen yazma becerisinin hangi basamakta ne düzeyde kazandırılabildiğin belirlenmesi, yapılan öğretimin niteliği ile ilgili de birtakım bilgiler (öğretimdeki boşluklar, eksikler, zorluklar gibi) ortaya koyacaktır. Bu nedenle bu çalışmada ortaya konan bulguların yazma becerisinin kazandırılmasına yönelik öğretime ve alan eğitimi alanyazınına, program geliştirme çalışmalarına ve kitap yazarlarına katkı sağlama potansiyeli yüksektir. 


\section{Model}

\section{Araştırmanın Modeli}

$\mathrm{Bu}$ araştırmada deneme türü esas alınarak ortaokul, lise ve lisans düzeyindeki öğrencilerin yazma performansları ortaya konmaya çalışılmıştır. Bu araştırma ortaokul, lise ve üniversite (lisans) öğrencilerinin yazma becerilerini detaylı bir biçimde ele alması, ortaya çıkan yapılar içerisinde nedensel bağlantı olduğu varsayılan olayları açklaması (Yin, 1984; akt: Subaşı ve Okumuş, 2017) bakımından kesitsel bir durum çalışmadır. Araştırmalar, verilerin toplanma zamanına göre anlık, kesitsel ve boylamsal olarak sınıflandırılır. Ayn grup üzerinde boylamsal bir çalışmanın zaman, maliyet, kontrol gibi güçlükler nedeniyle yapılamaması durumunda grubun zamana bağlı gelişimini temsilen alt grupların tek bir zamanda seçilip verilerin toplanması ise kesitsel araştırmaları tanımlar (Büyüköztürk, Kılıç Çakmak, Akgün, Karadeniz ve Demirel, 2016, s.13). Durum çalışmaları bir ya da daha fazla olayın, ortamın, programın ya da sosyal grubun derinlemesine incelendiği yöntem olarak tanımlanmaktadır. Araştırmalarda durum çalışmaları; a) Bir olayı meydana getiren ayrıntıları tanımlamak ve görmek b) Bir olayı değerlendirmek, bir olaya ilişkin olası açıklamaları geliştirmek amaçlariyla kullanılır (Büyüköztürk vd., 2016, s. 22; Creswell, 2016). Bu araştırmada ele alınan durum, ortaokul, lise ve üniversite öğrencilerinin yazma becerilerindeki gelişimin gözlenmesidir.

\section{Katılimcilar}

$\mathrm{Bu}$ araştırmanın katılımcıları İç Anadolu Bölgesi'nde yer alan bir devlet üniversitesinin eğitim fakültesinin farklı programlarında öğrenim gören 80 öğretmen adayı ile Konya il merkezindeki bir devlet lisesinin 12. sınıfına devam eden 80 öğrenci ve Konya il merkezindeki bir devlet ortaokulunun 8. sınıfına devam eden 80 öğrenciden oluşmaktadır. Öğrenciler gönüllülük esasına göre çalışmaya katılmışlardır. Deneme türüne Türkçe Dersi Öğretim Programında (MEB, 2018) en geniş kapsamda 8. sınıfta; Türk Edebiyatı Dersi Öğretim Programı ve Kılavuzunda (MEB, 2018) 12 . sinıfta yer verilmesi 
sebebiyle, bu çalışma ortaokul ve lise düzeyi için sekiz ve onikinci sınıfa devam eden öğrencilerle yürütülmüştür.

\section{Verilerin Toplanması}

Farklı öğretim düzeylerindeki öğrencilerin deneme türünde kaleme aldıkları kompozisyonlar bu araştırmanın veri kaynağını oluşturmuştur. Katılımc1lardan, aynı tema ile ilgili güdümlü yazma tekniğine uygun olarak kompozisyonlarını yazmaları istenmiştir. Katılımcılardan deneme türünde "İnsanlar niçin edebî eser okumalıdır?" sorusuna uygun olarak bir ders saatinde (ortalama 45 dakika), metin oluşturmaları istenmiştir. Öğrencilerin kendi el yazılarıyla kaleme aldıkları kompozisyonlar bu araştırmanın temel veri kaynağını oluşturmuştur. Çalışma, 2018-2019 öğretim yılının ekim, kasım ve aralık aylarında yapılmıştır.

\section{Verilerin Analizi}

$\mathrm{Bu}$ çalışmada verilerin analizinde, tematik/kategorik içerik analizi tekniği kullanılmıştır. Öğrenciler tarafından oluşturulan metinler, değerlendirme cetveline göre değerlendirilmiştir. Önceden belirlenen kategoriler ve bu kategorilere ait alt boyutlar belirlenerek kategorik analiz yapılmıştır. "Kategori analizi, genel olarak belirli bir mesajin önce birimlere bölünmesini ve ardından bu birimlerin, belirli kriterlere göre kategoriler hâlinde grupland1rılmasını ifade eder." (Bilgin, 1995, s.96-97).

\section{Değerlendirme Cetveli}

Öğrencilerin oluşturdukları metinleri değerlendirebilmek için Oktay'ın (2019) mektup ve hikâye türündeki yazıları değerlendirmek üzere oluşturduğu "değerlendirme cetveli" esas alınmıştır. Bu cetvel danışmanlığı tarafımca yürütülen yüksek lisans tez çalışmasında (Oktay, 2019) araştırmacı tarafından geliştirilmiştir. Söz konusu çalışma (Oktay, 2019) 2006 programları esas alınarak yürütüldügü için "değerlendirme cetveli" halihazırda kullanılan öğretim programları esas alınarak incelenmiş, cetvelde yer alan ölçütlerin halihazırda kullanılan öğretim programlarında karşılığının olması 
sebebiyle değerlendirme cetvelinin bu çalışmada herhangi bir değişiklik yapılmadan, mevcut haliyle kullanılmasına karar verilmiştir.

Metinlerde dış yapı olarak kâğıt düzenine (Kâğıdın kenarlarında, paragraf, satır aralarında uygun boşluk bırakılıp bırakılmadığı) ve metinlerin düzgün, okunaklı ve işlek bir yazı ile yazılıp yazılmadığına bakılmıştır.

Dil ve anlatımla ilgili değerlendirme ölçütlerinde başlık; ana fikir; yardımcı fikirler; alıntı, örnek ve benzetmelerin kullanılma durumu; sonuç ifadeleri; anlatım bozuklukları ve kaynak kullanımı gibi özelliklere bakılmıştır.

Yazım ve noktalama kategorisinde ise yazım kuralları ve noktalama işaretlerinin doğru kullanım durumlarına bakılmıştır.

Değerlendirme cetvelinde yer alan ölçütler kontrol listesi mantığıyla düşünülmüş, ilgili ölçütteki özeliklere göre yazılar değerlendirilmiştir. Çalışma daha çok hata analizine dayandığı için puanlama veya derecelendirmeli puanlama ölçeği hazırlanması yoluna gidilmemiştir. Çalışmada, ölçütün ölçtüğü özelliğin öğrencilerin yazılarında olup, olmadığı veya ölçüt kapsamında yapılan hatalar belirlenerek bunlara ait yüzdeler raporlanarak, ilgili tablolarda sunulmuştur. Bu çalışmadaki öğrenci kompozisyonlarının değerlendirilmesi daha çok hata analizine dayandığı için puanlama veya derecelendirmeli puanlama ölçeği hazırlanması yoluna gidilmemiştir. Bu çalışmada, değerlendirilen ölçütlere göre öğrencilere başarı puanları takdir etmek ve bu puanlar üzerinden ortaokul, lise ve lisans düzeyinde puana dayalı grup karşılaştırması yapmak, süreç temelli bir beceriyi ölçmek noktasında ölçme ve değerlendirme açısından uygun bulunmadığından, puan yerine uygunluk ve hata temelinde yüzdelik oranların verilmesi yaklaşımı benimsenmiştir.

Analizde değerlendirme cetvelinin nasıl kullanıldığı şöyle özetlenebilir: Öğrencinin yazdığı metin okunmadan önce metinde anlatılanlardan ve metindeki diğer özelliklerden etkilenmemek için biçim özellikleri bakımından metin alanı içindeki ve dışındaki boşluklara dikkat edilir. Metin baştan sona hızlı bir biçimde okunur. Bu okuyuşta öğrencinin yazısına alışılmaya çalışılır. Metinde anlatılan konu ve olay anlamaya çalışılır. İlk okuma sonunda -varsa- okunması güç olan sözcüklere dikkat edilir. Biçim özelliklerine puan verilir. $\mathrm{Bu}$ arada öğrencinin anlatımı hakkında bir fikir edinilir. Sözcük seçimi, cümle uzunlukları, paragraf bütünlüğü ve yazım ve noktalamada yapılan hatalar göz önünde bulundurulur. İkinci okuyuşta sözcük, 
cümle ve paragraf özelliklerine puan verilir. Bu aşamada niteleyici sözcüklere ve kalıplaşmış ifadelerin kullanılmasına; cümle yapılarına, dizilişlerine dikkat edilir. Değerlendirme cetvelinde yer alan özeliklere göre değerlendirilen yazıdaki olumlu ve olumsuz özellikler işaretlenerek sayılır ve elde edilen sayılara yüzdelik oran olarak gösterilir. Değerlendirme sürecinde kimi özelliklerin (biçim, yazım ve noktalama, cümle) puanlaması hata sayımına dayanır. Hata sayımında excel programı kullanılmıştır. Veriler excel programında yüzde hesapları alınarak çözümlenmiştir.

\section{Bulgular ve Yorumlar}

\section{Ortaokul Düzeyindeki Öğrencilerin Kaleme Aldıkları Yazılar Çerçevesinde Yazılı Anlatım Becerileri Hangi Düzeydedir?}

Tablo 1. Ortaokul 8. Sını Öğrencilerinin "Deneme" Türündeki Yazılarnna Yönelik Değerlendirme Cetveli

\begin{tabular}{llll}
\hline $\begin{array}{l}\text { DENEME } \\
\text { TÜRÜ }\end{array}$ & Yazılı anlatımda aranacak özellikler & Evet \% & Hayır \% \\
\hline $\begin{array}{llll}\text { Dış Yapı } \\
\text { (Biçim) }\end{array}$ & $\begin{array}{l}\text { Kâğıdın kenarlarında, paragraf ve satır aralarında uygun boşluklar } \\
\text { bırakılmıştır. }\end{array}$ & 53.75 & 46.25 \\
& Düzgün, okunaklı ve işlek bir yazı kullanılmıştır. & 53.75 & 46.25 \\
& Başlık konuyla ilgilidir. & 62,5 & 37,5 \\
& Konu, mantıksal tutarlılık ve bütünlük içinde anlatılmışıı. & 42.5 & 57.5 \\
& Paragraflar arasında uygun geçiş sağlanmıştır. & 27.5 & 72.5 \\
& Yazıda verilmek istenen temel iletiye/duyguya ulaşılmıştır. & 45 & 55 \\
& Ana fikir ve duygu, yardımcı fikir ve duygularla desteklenmiştir. & 22.5 & 77.5 \\
& Örnek ve benzetmeler yeterli olup içeriğe uygundur. & 15 & 85 \\
Dil ve & Sonuç bölümü metnin türüne uygun ve etkilidir. & 43.75 & 56.25 \\
Anlatım & Cümle kuruluşları dil bilgisi kurallarına uygundur. & 48.75 & 51.25 \\
(Üslup) & Kelimeler yerinde ve doğru anlamda kullanılmıştır. & 67.5 & 32.5 \\
& Cümlede kelime tekrarları yapılmamıştır. & 18.75 & 81.25 \\
Yazım & Konuyu kendine özgü ifadelerle anlatmıştır & 73.75 & 26.25 \\
Noktalama & Yazıda yazım kurallarına uyulmuştur. & 53.75 & 46.25 \\
\hline
\end{tabular}

Tablo 1. incelendiğinde sekizinci sınıf öğrencilerinin yazı kâğıdının kenarlarında, paragraf ve satır aralarında \%53.75 oranında uygun boşluklar bıraktıkları, \%46.25 oranında ise yazı kâğıdının kenarlarında, paragraf ve satır aralarında uygun boşluk bırakmadıkları görülmektedir. 
Düzgün, okunaklı ve işlek bir yazı kullanılmasında oran \%53.75 iken \%46.25 oranında düzgün, okunaklı ve işlek bir yazı kullanılmadığı tespit edilmiştir.

Başlığın konuyla ilgili olmasındaki oran \%62.5 iken başlığın konuyla ilgili olmamasinin oranı $\% 37.5^{\prime}$ tir.

Konunun mantıksal tutarlılık ve bütünlük içinde anlatılmasındaki oran \%57.5 iken konunun mantıksal tutarlılık ve bütünlük içinde anlatılmamasindaki oran $\% 42.5$ tir.

Paragraflar arasında uygun geçiş sağlanmasındaki oran \%27.5 iken paragraflar arasında uygun geçiş sağlanamamasında bu oran \% $72.5^{\prime}$ tir.

Yazıda verilmek istenen temel iletiye/duyguya ulaşılmasında \%45'lik bir oran var iken bu oran yazıda verilmek istenen temel iletiye/duyguya ulaş1lmamasında $\% 55$ 'tir.

Ana fikir ve ana duygunun yardımc fikir ve duygularla desteklenmesindeki oran \%26.5 iken ana fikir ve ana duyguyu yardımc fikir ve duygularla desteklememe oranı \%77.5'tir.

Örnek ve benzetmelerin yeterli olup içeriğe uygun olmasındaki oran $\% 15$ iken alıntı, örnek ve benzetmelerin içeriğe uygun olmaması oranı $\% 85^{\prime}$ tir.

Sonuç bölümünün metnin türüne uygun ve etkili olmasındaki oran \%43.75 iken sonuç ifadesinin konuyu bağlayıcı ve etkileyici olmamasındaki oran $\% 56.25$ 'tir.

Cümle kuruluşlarının dil bilgisi kurallarına uygun olmasında \%48.75'lik bir oran varken cümle kuruluşlarının dil bilgisi kurallarına uygun olmamasinda \%51.25'lik bir oran söz konusudur.

Kelimelerin yerinde ve doğru anlamda kullanılmasındaki oran \%62.5 iken kelimelerin yerinde ve doğru anlamda kullanılmamasındaki oranın $\% 37.5$ olduğu görülmüştür.

Cümlede kelime tekrarları yapılmamasında \%18.75'lik bir oran tespit edilmişken cümlede kelime tekrarları yapılmasında bu oran $\% 81.25$ olmuştur.

Konuyu kendine özgü ifadelerle anlatmadaki oran \%73.75 iken konuyu kendine özgü ifadelerle anlatamamada bu oran \%26.25'tir.

Yazıda yazım kurallarına uyulmasında \%53.75'lik bir oran söz konusu iken yazıda yazım kurallarına uyulmamasında bu oran \% 46.25 'tir. 
Noktalama işaretlerinin doğru yerde kullanılmasındaki oran \%52.25 iken noktalama işaretlerinin doğru yerde kullanılmamasındaki oran \% $47.75^{\prime}$ tir.

\section{Lise Düzeyindeki Öğrencilerin Kaleme Aldıkları Yazılar Çerçevesinde Yazı- ln Anlatım Becerileri Hangi Düzeydedir?}

Tablo 2. Lise 12. Sını Öğrencilerinin "Deneme" Türündeki Yazılarna Yönelik Değerlendirme Cetveli

\begin{tabular}{|c|c|c|c|}
\hline Deneme Türü & Yazılı anlatımda aranacak özellikler & $\begin{array}{l}\text { EVET } \\
\%\end{array}$ & $\begin{array}{l}\text { HAYIR } \\
\%\end{array}$ \\
\hline \multirow[t]{8}{*}{ Dış Yapı (Biçim) } & $\begin{array}{l}\text { Kâğıdın kenarlarında, paragraf ve satır aralarında uygun } \\
\text { boşluklar bırakılmıștır. }\end{array}$ & 36.25 & 63.75 \\
\hline & Düzgün, okunaklı ve işlek bir yazı kullanılmıştır. & 61.25 & 38.75 \\
\hline & Başlık konuyla ilgilidir & 51.25 & 48.75 \\
\hline & Konu, mantıksal tutarlılık ve bütünlük içinde anlatılmıştır & 51.25 & 48.75 \\
\hline & Paragraflar arasında uygun geçiş sağlanmıştır. & 43.75 & 56.25 \\
\hline & Yazıda verilmek istenen temel iletiye/duyguya ulaşılmıştır. & 71.25 & 28.75 \\
\hline & $\begin{array}{l}\text { Ana fikir ve duygu, yardımcı fikir ve duygularla desteklen- } \\
\text { miştir }\end{array}$ & 70 & 30 \\
\hline & Örnek ve benzetmeler yeterli olup içeriğe uygundur. & 56.25 & 43.75 \\
\hline \multirow{5}{*}{$\begin{array}{l}\text { Dil ve Anlatım } \\
\text { (Üslup) }\end{array}$} & Sonuç bölümü metnin türüne uygun ve etkilidir. & 67.5 & 32.5 \\
\hline & Cümle kuruluşları dil bilgisi kurallarına uygundur. & 56.25 & 43.75 \\
\hline & Kelimeler yerinde ve doğru anlamda kullanılmıştır & 85 & 15 \\
\hline & Cümlede kelime tekrarları yapılmamıştır. & 35 & 45 \\
\hline & Konuyu kendine özgü ifadelerle anlatmıştır & 100 & 0 \\
\hline Yazım & Yazıda yazım kurallarına uyulmuştur. & 43.75 & 56.25 \\
\hline ve Noktalama & Noktalama işaretleri doğru yerde kullanılmıştır. & 48.75 & 51.25 \\
\hline
\end{tabular}

Tablo 2. incelendiğinde 12. sınıf öğrencilerinin kâğıdın kenarlarında, paragraf ve satır aralarında uygun boşluklar bırakılmasında \%36.25'lik bir oran görülürken kâğıdın kenarlarında, paragraf ve satır aralarında uygun boşluklar bırakılmamasındaki oran \%63.75'tir.

Düzgün, okunaklı ve işlek bir yazı kullanılmasındaki oran \%61.25 iken \%38.75 oranında düzgün, okunaklı ve işlek bir yazı kullanılmadığı tespit edilmiştir.

Başlığın konuyla ilgili olmasındaki oran \%51.25 iken başlığın konuyla ilgili olmamasının oranı \% 48.75 'tir.

Konunun mantıksal tutarlılık ve bütünlük içinde anlatılmasında $\% 51.25^{\prime}$ lik bir oran varken konunun mantıksal tutarlılık ve bütünlük içinde anlatılmamasındaki oran $\% 48.75$ olmuştur. 
Paragraflar arasında uygun geçiş sağlanmasında \%43.75'lik bir oran görülürken paragraflar arasında uygun geçiş sağlanmamasında bu oran $\% 56.25$ 'tir.

Yazıda verilmek istenen temel iletiye/duyguya ulaşılmasında \%71.25'lik bir oran var iken yazıda verilmek istenen temel iletiye/duyguya ulaşılmamasinda bu oran \%28.75'tir.

Ana fikir ve ana duygunun yardımc fikir ve duygularla desteklenmesinde \%70'lik bir oran görülürken ana fikir ve ana duygunun yardımc fikir ve duygularla desteklenmemesindeki oran $\% 30$ olarak tespit edilmiştir.

Örnek ve benzetmelerin yeterli olup içeriğe uygun olmasındaki oran \%56.25 iken alıntı, örnek ve benzetmelerin yetersiz veya içeriğe uygun olmaması oranı $\% 43.75^{\prime}$ tir.

Sonuç bölümünün metnin türüne uygun ve etkili olmasında \%67.5'lik bir oran görülürken sonuç ifadesinin konuyu bağlayıc ve etkileyici olmamasindaki oran \%37.5'tir.

Cümle kuruluşlarının dil bilgisi kurallarına uygun olmasında \%56.25'lik oran varken cümle kuruluşlarının dil bilgisi kurallarına uygun olmamasında \%43.75'lik bir oran söz konusudur.

Kelimelerin yerinde ve doğru anlamda kullanılmasındaki oran \%85 iken kelimelerin yerinde ve doğru anlamda kullanılmamasındaki oranın \%15 olduğu görülmüştür.

Cümlede kelime tekrarları yapılmamasındaki oran \%35 iken cümlede kelime tekrarları yapılmasındaki oran \%45 olmuştur.

Konuyu kendine özgü ifadelerle anlatma oran \%100 iken konuyu kendine özgü ifadelerle anlatmamada bu oran $\% 0^{\prime}$ dır.

Yazıda yazım kurallarına uyulmasında \%43.75'lik bir oran söz konusu iken yazıda yazım kurallarına uyulmamasının oranı $\% 56.25$ 'tir.

Noktalama işaretlerinin doğru yerde kullanılmasında \%48.75'lik bir oran görülürken noktalama işaretlerinin doğru yerde kullanılmamasında bu oran $\% 51.25^{\prime}$ tir. 


\section{Lisans Düzeyindeki Öğrencilerin Kaleme Aldıklarn Yazılar Çerçevesinde Yazılı Anlatım Becerileri Hangi Düzeydedir?}

Tablo 3. Lisans 3. Sınıf Öğrencilerinin “Deneme” Türündeki Yazılarına Yönelik Değerlendirme Cetveli

\begin{tabular}{|c|c|c|c|}
\hline $\begin{array}{l}\text { Deneme } \\
\text { Türü }\end{array}$ & Yazılı anlatımda aranacak özellikler & $\begin{array}{l}\text { EVET } \\
\%\end{array}$ & $\begin{array}{l}\text { HAYIR } \\
\%\end{array}$ \\
\hline \multirow{8}{*}{$\begin{array}{l}\text { Diş Yapı } \\
\text { (Biçim) }\end{array}$} & $\begin{array}{l}\text { Kâğıdın kenarlarında, paragraf ve satır aralarında uygun boşluklar } \\
\text { bırakılmıştır. }\end{array}$ & 78.75 & 21.25 \\
\hline & Düzgün, okunaklı ve işlek bir yazı kullanılmıştır. & 78.75 & 21.25 \\
\hline & Başlık konuyla ilgilidir & 46.25 & 53.75 \\
\hline & Konu, mantıksal tutarlılık ve bütünlük içinde anlatılmıştır & 77.5 & 22.5 \\
\hline & Paragraflar arasında uygun geçiş sağlanmıştır. & 66.25 & 33.75 \\
\hline & Yazıda verilmek istenen ana fikre ulaşılmıştır. & 76.25 & 23.75 \\
\hline & Ana fikir ve duygu, yardımcı fikir ve duygularla desteklenmiştir & 75 & 25 \\
\hline & Örnek ve benzetmeler yeterli olup içeriğe uygundur. & 48.75 & 51.25 \\
\hline \multirow{6}{*}{$\begin{array}{l}\text { Dil ve } \\
\text { Anlatım } \\
\text { (Üslup) }\end{array}$} & Sonuç bölümü metnin türüne uygun ve etkilidir. & 76.25 & 23.75 \\
\hline & Cümle kuruluşları dil bilgisi kurallarına uygundur. & 76.25 & 23.75 \\
\hline & Kelimeler yerinde ve doğru anlamda kullanılmıştır & 90 & 10 \\
\hline & Cümlede kelime tekrarları yapılmamıştır. & 12.5 & 87.5 \\
\hline & Konuyla ilgili kaynaklara başvurulmuş ve yeterince yararlanılmıştır & 48,75 & 51,25 \\
\hline & Konuyu kendine özgü ifadelerle anlatmıştır & 97.5 & 2.5 \\
\hline \multirow{2}{*}{$\begin{array}{l}\text { Yazım } \\
\text { ve Nokta- } \\
\text { lama }\end{array}$} & Yazıda yazım kurallarına uyulmuştur. & 76.25 & 23.75 \\
\hline & Noktalama işaretleri doğru yerde kullanılmıştır. & 80 & 20 \\
\hline
\end{tabular}

Tablo 3. incelendiğinde lisans üçüncü sınıf öğrencilerinin kâğıdın kenarlarında, paragraf ve satır aralarında uygun boşluklar bırakmalarındaki oran \%78.75 iken kâğıdın kenarlarında, paragraf ve satır aralarında uygun boşluklar birakılmamasındaki oran \%21.25'tir.

Düzgün, okunaklı ve işlek bir yazı kullanılmasındaki oran \%78.75 iken \%21.25 oranında düzgün, okunaklı ve işlek bir yazı kullanılmadığı tespit edilmiştir.

Başlığın konuyla ilgili olmasında \%46.25'lik bir oran görülürken başlığın konuyla ilgili olmamasının oranı $\% 53.75$ 'tir.

Konunun mantıksal tutarlılık ve bütünlük içinde anlatılmasında \%77.5'lik bir oran varken konunun mantıksal tutarlılık ve bütünlük içinde anlatılmamasındaki oran \%22.5 olmuştur. 
Paragraflar arasında uygun geçiş sağlanmasında \%66.25'lik bir oran görülürken paragraflar arasında uygun geçiş sağlanmamasında bu oran $\% 33.75$ 'tir.

Yazıda verilmek istenen temel iletiye/duyguya ulaşılmasında \%76.25'lik bir oran var iken bu oran yazıda verilmek istenen temel iletiye/duyguya ulaşılmamasında \%23.25'tir.

Ana fikir ve ana duygunun yardımc fikir ve duygularla desteklenmesindeki oran \%75 iken ana fikir ve ana duygunun yardımc fikir ve duygularla desteklenmemesindeki oran $\% 25$ olarak tespit edilmiştir.

Örnek ve benzetmelerin yeterli olup içeriğe uygun olmasındaki oran \%48.75 iken alıntı, örnek ve benzetmelerin yetersiz veya içeriğe uygun olmaması oranı $\% 51.25$ tir.

Sonuç bölümünün metnin türüne uygun ve etkili olmasında \%76.25'lik bir oran görülürken sonuç ifadesinin konuyu bağlayıc ve etkileyici olmamasinda bu oran \%23.75'tir.

Cümle kuruluşlarının dil bilgisi kurallarına uygun olmasında \%76.25'lik bir oran varken cümle kuruluşlarının dil bilgisi kurallarına uygun olmamasinda \%23.75'lik bir oran söz konusudur.

Kelimelerin yerinde ve doğru anlamda kullanılmasındaki oran \%90 iken kelimelerin yerinde ve doğru anlamda kullanılmamasındaki söz konusu oranın \%10 olduğu görülmüştür.

Cümlede kelime tekrarları yapılmamasındaki oran \%12.5 iken cümlede kelime tekrarları yapılmasında bu oran \%87. 5 olmuştur.

Konuyu kendine özgü ifadelerle anlatmada \%97.5'lik bir oran görülürken konuyu kendine özgü ifadelerle anlatmamada söz konusu oran \%2.5'tir.

Yazıda yazım kurallarına uyulmasında \%76.25'lik bir oran söz konusu iken yazıda yazım kurallarına uyulmamasında bu oran \%23.75'tir.

Noktalama işaretlerinin doğru yerde kullanılmasındaki oran \%80 iken noktalama işaretlerinin doğru yerde kullanılmamasındaki oran $\% 20^{\prime}$ dir.

\section{Tartışma ve Sonuç}

1. Kâğıdın kenarlarında, paragraf ve satır aralarında uygun boşluklar bırakma hususunda ortaokul düzeyindeki öğrencilerin \%53.75, lise düzeyindeki öğrencilerin \%36.25 ve lisans öğrencilerinin \%78.75 oranında başarılı oldukları tespit edilmiştir. Bu sonuçlara göre kâğıdın kenarlarında, paragraf 
ve satır aralarında uygun boşluklar bırakma hususunda dikkat çekici bir biçimde ortaokul öğrencilerinin lise öğrencilerinden daha başarılı oldukları gözlenmiştir. Bu kategorideki en yüksek oranın lisans öğrencileri tarafından ortaya konulması düzeye paralel bir artış olarak açıklanabilir.

Ankara Büyükşehir Belediyesi sınırları içindeki çeşitli ortaokullarda öğrenim gören 585 sekizinci sınıf öğrencisi ile yapılan benzer bir çalışmada (Demir, 2013, s.47) "öğrencilerin kâğıt ve sayfa düzenine dikkat etme" kategorisinde \%60 oranında başarılı oldukları bulgusuna yer verilmiştir. $\mathrm{Bu}$ oran çalışmamızdaki bulguları destekleyici mahiyettedir.

İlkokul 5. sınıf öğrencilerinin yazdıkları hiâye türündeki metinler üzerinden yapılan diğer bir çalışmada da (Eğilmez ve Berber, 2017, s.173) kâğgda yazıyı düzgün yerleştirme açısından hikâyeler değerlendirildiğinde, öğrencilerin $\% 28$ 'inin birinci düzeyde kaldığ 1 \% $\% 40^{\prime}$ ının orta düzeyde başarılı olduğu ve \%30'unun sayfa kenarlarında uygun boşluklar bırakarak kâğgda yazıyı düzgün bir şekilde yerleştirdikleri ve böylece üçüncü düzeyde yer aldıkları bulgusu paylaşılmıştır. Üniversite öğrencilerinin yazılı anlatımlarının değerlendirildiği çalışmada Arıcı (2008) örnekleme katılan yaklaşık her beşöğrenciden birinin (\%19.2) yazdığı yazıda kâğıt düzenine yeterince özen göstermediğini belirtirken Derman (2010) ise bu kategoride lisans düzeyindeki öğrencilerin kâğıt düzeniyle ilgili olarak \%25 oranında hata yaptıklarını tespit etmiştir. Bu rakamlar öğrencilerin genel olarak kâğıt düzeniyle ilgili kurallara uyma ve hata yapmama hususundaki yetkinliklerinin ortalamanın üzerinde ve başarılı olduğu sonucunu ortaya koymaktadır.

2. Düzgün, okunaklı ve işlek bir yazı kullanma hususunda, ortaokul düzeyindeki öğrencilerin \%53.75, lise düzeyindeki öğrencilerin \%61.25 ve lisans öğrencilerinin \%78.75 oranında başarılı oldukları tespit edilmiştir.

Çalışmamıza benzer olarak ortaokul, lise ve üniversite düzeyindeki öğrencilerin mektup ve hikâye türündeki yazılarının değerlendirildiği yüksek lisans tezinde, (Oktay, 2019) bu kategoride mektup türünde ilköğretimde \% 56.25 , ortaöğretimde $\% 46.25$ ve lisans düzeyinde \%80; hikâye türünde ilköğretimde $\% 48.75$, ortaöğretimde $\% 37.5$ ve lisans düzeyinde $\% 82.5$ oranlarında başarılı oldukları bulgularına ulaşılmıştır. Bu oranlar çalışmamızın sonuçlarıyla uyumludur ancak çalışmamızda farklı düzeylerdeki öğrenciler arasında ortaokul düzeyinden lisans düzeyine doğru beklenen kademeli bir artış olduğu gözlenmiştir. 
3. Başlığı konuyla ilişkilendirme hususunda, ortaokul düzeyindeki öğrencilerin \%62.5, lise düzeyindeki öğrencilerin \%51.25 ve lisans öğrencilerinin \%46.25 oranında başarılı oldukları tespit edilmiştir. Burada beklenmedik bir biçimde öğretim düzeyi arttıkça doğru kullanıma yönelik oranların azaldığı görülmektedir. Lise ve lisans öğrencilerinin ortaokul öğrencilerine göre daha başarısız olmaları yazıya uygun başlık oluşturmayı bilmemelerinden ziyade yeterli motivasyona sahip olmadıkları, bu hususu yeterince dikkate almadıklarıyla açıklanabilir.

Eğilmez ve Berber, (2017) çalışmalarında öğrencilerin hikâyeleri için seçtikleri başlıkların değerlendirmiş ve öğrencilerin \%89'unun, hikâyenin konusunu doğrudan başlık olarak yazdıklarını, metne özgün bir başlık koyamadıklarını; \%4'ünün konuya uygun ve çarpıc bir başlık yazabildiklerini; $\% 6$ 'sının ise hiç başlık yazmadıklarını belirtmektedirler.

Demir, (2013) yazıya, konuyla ilgili kısa ve dikkat çekici bir başlık bulma noktasında ortaokul öğrencilerinin orta düzeyde (\%57) başarılı olduklarını belirtirken Arıcı (2008) üniversite öğrencilerinin başlıkla ilgili hata oranlarını \%7.2, Derman (2010) ise \%20 olarak belirlemişlerdir ki bu oranlar, bu çalışmadaki hata oranlarına göre $(54,75)$ oldukça düşüktür. Bu durum araştırmacının kontrolü dışında uygulama için seçilen zamanın öğrenciler için uygun düşmemesiyle, öğrencilerin uygulama için yeterince güdülenemedikleriyle veya uygulamayı geçiştirme psikolojisiyle özensiz ve çalakalem yaptıklarıyla açıklanabilir.

4. Konunun mantıksal tutarlılık ve bütünlük içinde anlatılması hususunda, ortaokul düzeyindeki öğrencilerin $\% 42.5$, lise düzeyindeki öğrencilerin $\% 51.25$, lisans öğrencilerinin \%77.5 oranında başarılı oldukları tespit edilmiştir. Burada ortaokul düzeyinden lisans düzeyine doğru kademeli bir artış gözlenmiştir. Bu artış, beklenen bir sonuç olarak değerlendirilebilir. Çalışmamızın bulguları farklı türlerde yazılan metinler (mektup, öykü) üzerinden yapılan Oktay'ın (2019) çalışmasındaki sonuçlarla uyumludur. Oktay, bu kategoriye yönelik olarak mektup türünde ilköğretimde \% 48.75, ortaöğretimde \% 72.5, lisans düzeyinde \%90; hikâye türünde ilköğretimde $\% 57.5$, ortaöğretimde \% 77.5, lisans düzeyinde \% 65 oranında bir başarı belirlemiştir.

5. Paragraflar arası geçiş sağlayabilme hususunda ortaokul düzeyindeki öğrencilerin \%27.5, lise düzeyindeki öğrencilerin \%43.75 ve lisans öğrencilerinin \%66.25 oranında başarılı oldukları tespit edilmiştir. Burada da ortao- 
kul düzeyinden lisans düzeyine doğru beklenen kademeli bir artış olduğu sonucuna ulaşılabilir ancak diğer kategorilere nazaran paragraflar arası geçiş sağlayabilme hususunda ortaokul öğrencilerinin çok başarısız, lise öğrencilerinin başarısız, lisans öğrencilerinin ise orta seviyede başarılı oldukları görülmektedir. Lisans öğrencilerinin bu kategorideki başarı durumları Karatay'ın (2010) öğretmen adaylarıyla yaptı̆̆ çalışmanın sonuçlarıyla paralellik göstermektedir.

Genel anlamda öğrencilerin başarı oranlarının düşüik kalması, öğretim kademelerinde yazının planlanması, paragraf oluşturma, taslağa uygun paragraf geçişleri sağlama husularında nitelikli bir öğretimin yapılamadığ1nı ortaya koymaktadır. Ayrıca metin oluştururken bağdaşıklık ve tutarlılık özelliklerinin kavratılamadığı, bu konuyla ilgili dil bilgisi yapılarının işlevsel ve uygulamalı bir biçimde metin bağlamında işlenmediği de söyelenebilir. Nitekim Kan ve Tiryaki'nin (2015) çalışmasında "paragrafta cümleler arasında uygun geçişler sağlanmaması" kategorisinde Türkçe öğretmeni adaylarının \%81,37 oranında başarısız olmaları durumun vehametini gözler önüne sermektedir.

6. Yazıda verilmek istenen temel iletiyi/duyguyu, ana fikri işleme hususunda, ortaokul düzeyindeki öğrencilerin \%45, lise düzeyindeki öğrencilerin \%71.25 ve lisans öğrencilerinin \%76.25 oranında başarılı oldukları tespit edilmiştir. Bu kategoride de ortaokul düzeyinden lisans düzeyine doğru kademeli bir artış gözlemlenmiştir. Çalışmamızın bulgularında ortaya çıkan oranlar Oktay'ın (2019) çalışmasıyla uyumludur.

7. Ana fikri yardımc fikirlerle destekleme hususunda, ortaokul düzeyindeki öğrencilerin \%22.5, lise düzeyindeki öğrencilerin \%70 ve lisans öğrencilerinin \%75 oranında başarılı oldukları tespit edilmiştir. Bu sonuçlar ortaokul düzeyinden lisans düzeyine doğru olumlu yönde bir artış olduğunu ortaya koymaktadır ancak ortaokul öğrencilerinin başarı yüzdesi lise ve lisans düzeyiyle karşılaştırıldığında oldukça düşük kalmaktadır. Bu durumun ortaya çımasında, öğrencilerin farklı metinlerden hareketle ana fikir ve onu destekleyen yardımc fikirlerin metinlerde nasıl yer aldığın belirlemeye yönelik anlama çalışmalarına yeterince maruz kalmadıkları ve bunun yanında ana fikir ve yardımcı fikir kavramlarını uygulamalı olarak pekiştirecekleri taslaktan hareketle bilgilendirici metin yazmayla ilgili yeterince etkinlik yapmadıkları ileri sürülebilir. 
Ana fikir ve onu destekleyen yardımc fikirlerin metinlerde istenen nitelik ve seviyede kullanılmadığına yönelik farklı öğretim kademelerine yönelik Demir (2013), Arıcı (2008), Arıcı ve Ungan (2008), Eğilmez ve Berber (2017), Derman (2010) tarafından yapılan çalışmalarda benzer sonuçları ortay koymuştur. Söz konusu araştırmalardaki sonuçlar araştırmamızın sonuçlarıyla paralellik göstermektedir.

8. Yazıda örnek ve benzetmelere yeterince yer verme ve kullanılan örnek ve benzetmelerin içeriğe uygun olması hususunda, ortaokul düzeyindeki öğrencilerin \%15, lise düzeyindeki öğrencilerin \%56.25 ve lisans öğrencilerinin \%48.75 oranında başarılı oldukları tespit edilmiştir. Bu kategorideki yüzdelik dağılımların dengeli bir biçimde oluşmadıkları göze çarpmaktadır. Ortaokul öğrencilerinin başarı yüzdeleri diğer öğretim kademelerindeki öğrencilere göre oldukça düşükken lisans öğrencilerinin az bir farkla da olsa lise öğrencilerine göre daha başarısız olmaları dikkat çekicidir.

Oktay, bu kategoriye yönelik olarak mektup türünde ilköğretimde \% 15, ortaöğretimde $\% 55$, lisans düzeyinde $\% 18.5$; hikâye türünde ilköğretimde $\% 17.5$, ortaöğretimde $\% 62.5$, lisans düzeyinde $\% 12.5$ oranında bir başarı belirlemiştir. Çalışmalardaki bulgulara ait oranların hem çalışmalara hem de öğrenim seviyelerine göre birbirlerinden oldukça farklılaşması öncelikle kaleme alınan metin türünün özellikleriyle ilişkilendirilebilir. Deneme türünde hem benzetme hem de örnekler yer alabilirken hikâye türünde örnekten ziyade benzetmeler kullanılabilir. Mektup ise örnek vermek için daha uygun bir tür olarak nitelendirilebilir.

9. Sonuç ifadesinin konuyu bağlayıcı ve etkileyici olması hususunda, ortaokul düzeyindeki öğrencilerin \%43.75, lise düzeyindeki öğrencilerin $\% 67.5$, lisans öğrencilerinin \%76.25 oranında başarılı oldukları tespit edilmiştir. Bu durum ortaokul düzeyinden lisans düzeyine doğru kademeli bir artışın olduğunu göstermektedir.

Demir (2013), yazıyı etkili ifadelerle sonuçlandırma kategorisinde \%76'lık bir oran belirlerken Oktay (2019) mektup türünde ilköğretimde \% 27.5 , ortaöğretimde $\% 45$, lisans düzeyinde $\% 91.25$; hikâye türünde ilköğretimde $\% 48.75$, ortaöğretimde $\% 51.25$, lisans düzeyinde $\% 53.75$ lik bir oranı belirlemiştir. Bu sonuçlar elde ettiğimiz bulgularla uyumludur.

Kan ve Tiryaki'nin (2015) \%65,69 oranında sonuç paragrafı yapılmadı̆̆ına yönelik bulgusu, çalışmanın katılımcılarının Türkçe öğretmeni adayları oldukları göz önünde bulundurulduğunda oldukça dikkat çekicidir. Kaldı 
ki yönergede öğretmen adaylarına sunulan yazma konusu, sonuç paragrafının kolaylıkla oluşturulabileceği "Sıkı bir maratondan sonra KPSS'ye girdiniz ve çok iyi bir puan aldınız. Artık istediğiniz yerde Türkçe öğretmenisiniz. Şimdi neler yapacağınızı bizimle paylaşır mısınız?" konusudur.

10. Cümle kuruluşlarının kurallara uygun olması hususunda, ortaokul düzeyindeki öğrencilerin \%48.75, lise düzeyindeki öğrencilerin \%56.25, lisans öğrencilerinin \%76.25 oranında başarılı oldukları tespit edilmiştir. Burada yine beklentilere uygun olarak ortaokul düzeyinden lisans düzeyine doğru kademeli bir artış gözlemlenmektedir.

11. Kelimelerin yerinde ve doğru anlamda kullanılması hususunda, ortaokul düzeyindeki öğrencilerin \%67.5, lise düzeyindeki öğrencilerin \%85 ve lisans öğrencilerinin \%90 oranında başarılı oldukları tespit edilmiştir. Bu hususta ortaokul düzeyinden lisans düzeyine doğru kademeli bir artışın olmasının yanında başarı oranlarının her kademede oldukça yüksek oranda oluşu dikkate değerdir.

12. Cümlede gereksiz sözcük tekrarı yapılmaması hususunda, ortaokul düzeyindeki öğrencilerin \%18.75, lise düzeyindeki öğrencilerin \%35 ve lisans öğrencilerinin \%12.5 oranında gereksiz sözcük tekrarı yaptıkları görülmektedir. Bu kategorideki değerlendirmeye yönelik ifadenin olumsuz olduğu ve bu kategorideki oranların ters yüzdeler olduğu göz önüne alındığında öğrencilerin başarı oranlarının yüksek olduğu söylenebilir. Bu kategoride lise öğrencilerinin gereksiz sözcük tekrarı yapma oranlarının diğer öğretim kademesindeki öğrencilerin oranlarına nazaran yüksek oluşu dikkat çekicidir.

13. Konuyu kendine özgü ifadelerle anlatabilme hususunda, ortaokul düzeyindeki öğrencilerin \%73.75, lise düzeyindeki öğrencilerin \%100, lisans öğrencilerinin \%97.5 oranında başarılı oldukları tespit edilmiştir.

14. Yazım kurallarına uyulması hususunda, ortaokul düzeyindeki öğrencilerin $\% 53.75$, lise düzeyindeki öğrencilerin $\% 43.75$, lisans öğrencilerinin \%76.25 oranında başarılı oldukları tespit edilmiştir. Bu oranlara göre lise öğrencilerinin yazım kurallarına uyulması hususunda daha çok hata yapmaları dikkat çekicidir. Benzer bir durum bir sonraki kategori olan noktalama işaretlerini doğru yerde kullanma hususunda da benzer bir biçimde karşımıza çıkmaktadır.

Eğilmez ve Berber, (2017) bu hususta öğrencilerin \%47'sinin oldukça başarısız olduğunu; \%43'ünün orta düzeyde başarılı olduğunu ve \%11'inin 
hikâyesinin tamamında yazım kurallarına uygun yazdığını belirlemişlerdir. Demir (2013) ise yazım kurallarını kavrayarak uygulama oranının \%43 olduğunu belirtmektedir. Bu veriler çalışmamızın verileriyle oldukça uyumludur.

15. Noktalama işaretlerini doğru yerde kullanma hususunda, ortaokul düzeyindeki öğrencilerin \%52.5, lise düzeyindeki öğrencilerin \%48.75, lisans öğrencilerinin ise \%80 oranında başarılı oldukları tespit edilmiştir.

Bu kategoride Eğilmez ve Berber, (2017) çalışmalarında yer alan katılımclların \%17'sinin noktalama işaretlerini kullanma konusunda oldukça eksik kaldıklarını, \%51'inin yazılarının tamamında noktalama işaretlerini doğru kullanamadıklarını \%32'sinin ise noktalama işaretlerini doğru ve uygun olarak kullandıklarını belirtmektedir.

Arı (2010), Altıncı ve Yedinci sınıf öğrencilerinin hikâye türündeki yazılarını değerlendirdiği çalışmasında altıncı sınıfta okuyan erkek öğrencilerin yazım ve noktalama kullanımlarına yönelik düzeylerini $\% 64,2$ oranında yetersiz, \%30,4 oranında orta, \%5,4 oranında iyi, \%0 oranında çok iyi; kız ögrecilerin oranlarını ise $\% 41,2$ oranında yetersiz, \%39,8 oranında orta, $\% 14,4$ oranında iyi, \%4,6 oranında çok iyi olarak sınıflandırmıştır. Yedinci sinuflarda da benzer oranlar görülmektedir. Bu sonuçlar öğrencilerin bu kategoride genel olarak yetersiz olduklarını ortaya koymaktadır.

Bu oran Demir'in çalışmasında (2013) da aynıdır (\%32). Derman (2010), Türkçe öğretmen adaylarının \%70'inin imla, \%28,75'inin noktalama hatası yaptıklarını ortaya koymaktadır.

Arıcı ve Ungan (2008) da benzer sonuçlar ortaya koymuşlardır. Bağc (2010) ise noktalama ve imla bilgisine yönelik olarak Türkçe öğretmeni adaylarının başarı oranını $\% 66$ olarak belirtmektedir.

Özbay (1995), Ekinci Çelikpazu (2006), İnce (2006), Ayyıldız ve Bozkurt (2006), Büyükikiz (2007), Oktay (2019) gibi araştırmacıların çalışmalarında da yazım ve noktalama yanlışlarının yapılmasına yönelik benzer tespitler yer almaktadır. Söz konusu araştırmalardaki sonuçlar araştırmamızın sonuçlarıyla paralellik göstermektedir.

Bu sonuçlar doğrultusunda şu önerilere yer verilebilir:

- Öğrencilerin yazma becerilerindeki hatalarını ortadan kaldırmaya yönelik öğretim tasarlama ilkelerine uygun çalışmalara ağırlık verilmelidir. 
- Öğrencilerin yazma becerilerindeki hata merkeze alan ve hata çözümlemeleri üzerinden öğrencilerdeki farkındalığı arttırmaya yönelik çalışmalara ağırlık verilmelidir.

- Yazma becerisinin geliştirilmesine yönelik dersler daha işlevsel ve uygulamaya dayalı olarak işlenmelidir.

- Farklı edebî türlerde daha nitelikli yazıların üretimini sağlayacak hayatla iç içe, öğrenciyle uyumlu yazma atelyeleri oluşturulabilir.

- Öğretim programlarındaki kazanımların çok soyut ve kapsamlı oluşu, yazılı anlatımda türlerin nasıl öğretileceği ile ilgili müfredat boşlukları oluşturmaktadır. Ders kitaplarında, türlerin yazımına yönelik tema önerilerinin dişında türlerin nasıl yazılacağını kavratmaya yönelik aşamalı etkinliklerin de bulunması yararlı olacaktır.

- Bu çalışmada değerlendirilen ölçütler dışında öğrencilerin yazılarını estetik dil kullanımı açısından değerlendirmeye yönelik çalışmalar yapılabilir. 


\section{EXTENDED ABSTRACT}

\section{Evaluation of Written Expression Skills of Experiment Type of Students in Different Teaching Levels \\ Serdar Derman \\ Necmettin Erbakan University}

Language skills consist of four basic language skills: understanding (listening-reading) and telling (speaking-writing). Students first gain basic reading and writing skills with the beginning of formal education within the acquisition process of the mother tongue.

Being able to write effectively and well depends on getting a good writing education and applying it. Moving from this fact, giving education to students starting from childhood, examining their writings and revealing their mistakes and working accordingly can contribute to the development of these skills and therefore to be able to write well. An important part of writing education is given in the primary education period.

It is at least as valuable for teachers as it is important for students to identify errors in writing skills, to arrange, grasp and developmental feedback, in terms of planning, organizing, completing and eliminating deficiencies.

In this study, it was tried to determine the general status of the education levels and the types of errors made by evaluating the essay type, which is one of the informative text types of secondary school, high school and university students. Creating informative texts is one of the issues that are emphasized in secondary and high school curriculum.

In this study, it is aimed to evaluate the written expression skills of the students at the middle, high school and undergraduate level through essays and to compare the written expression skills of the students.

In addition to the aforementioned issue, good speaking and writing skills are seen as an important skill field in all disciplines within the framework of basic teacher competencies. It will also reveal some information (such as gaps, deficiencies, difficulties in teaching) about determi- 
ning the level of writing skill that is aimed to be gained at different levels of formal education, and at what level, and the quality of the education. For this reason, it has a high potential to contribute to teaching and field education literature, program development studies and book writers to gain the writing skills of the findings revealed in this study.

In this study, writing performances of middle school, high school and undergraduate students were tried to be determined based on the essay writing. This research is a cross-sectional case study in terms of detailed handling of writing skills of secondary school, high school and university (undergraduate) students, explaining the events that are assumed to be a causal connection among the emerging structures. The situation addressed in this research is the observation of the improvement in the writing skills of middle school, high school and university students.

The participants of this study were 80 teachers from different programs of the Faculty of education of a State University in the Central Anatolia region and 12 from a state High School in the central Konya province. 80 students attending class and 8 of a state secondary school in the city center of Konya. It consists of 80 students who attend its class.

The essays written by students at different levels of education in the essay type formed the data source of this research. Thematic content analysis was used in the analysis of the data. In order to evaluate the texts the students created, an "evaluation chart" containing criteria related to external structure (form), language and expression (style), spelling and punctuation were used.

As a result of the analysis, a gradual increase in criteria such as paper layout, using a smooth, legible and busy writing, explaining the subject with logical consistency and integrity, being able to pass between paragraphs, processing the main idea, main feeling, tendency, supporting the subject with helpful ideas, making the result statement binding and expressive, making sentences according to the rules, using the words in a proper and correct sense was determined by different levels of teaching. It was determined that there was no balanced increase in the criteria such as associating the title with the subject, not repeating unnecessary words in the sentence, following the spelling rules, using punctuation marks in the right place. 
The findings were compared with the related studies and some inferences were made about teaching.

In line with these results, the following suggestions can be included:

- Studies that comply with the principles of teaching design to eliminate students' mistakes in writing skills should be emphasized.

- Emphasis should be placed on studies focusing on students' writing skills and increasing their awareness through error analysis.

- Lessons to improve writing skills should be taught more functional and practice-based.

- Writing workshops that are compatible with the student and which are compatible with life, can be created to provide the production of more qualified articles in different literary genres.

- The fact that the achievements in the curriculum are very abstract and comprehensive creates curriculum gaps regarding how to teach the types in written expression. In the textbooks, it would be useful to find gradual activities to understand how the genres are written, besides the theme suggestions for the writing of genres.

- Apart from the criteria evaluated in this study, studies can be conducted to evaluate students' writings in terms of aesthetic language use.

\section{Kaynakça / References}

Arı, G. (2010). Altıncı ve yedinci sınıf öğrencilerinin yazdığı hikâye edici metinlerin değerlendirilmesi. TÜBAR, 27, 43-75.

Arıcı, A. F. (2008). Üniversite öğrencilerinin yazılı anlatım hataları. Uludă̆ Üniversitesi Eğitim Fakültesi Dergisi, 21(2), 209-220.

Arıcı, A. F. ve Ungan, S. (2008). İlköğretim ikinci kademe öğrencilerinin yazili anlatim çalişmalarinin bazi yönlerden değerlendirilmesi. Dumlupinar Üniversitesi Sosyal Bilimler Dergisi, 20.

Ayyıldız, M. ve Bozkurt, Ü. (2006). Edebiyat ve kompozisyon eğitiminde karşılaşılan sorunlar, Türk Eğitim Bilimleri Dergisi, 4(1), 45-52.

Bağcı, H. (2010). Türkçe öğretmeni adaylarının yazılı anlatım yeterlilik düzeyleri. İnönü Üniversitesi Ĕ̆itim Fakültesi Dergisi, 11(2), 45-68.

Bilgin, N. (1995). Sosyal psikolojide yöntem ve pratik çalışmalar. İstanbul: Sistem Yayıncilik. 
Büyükikiz, K. K. (2007). İlköğretim 8. sinıföğrencilerinin yazılı anlatım becerilerinin söz dizimi ve anlatım bozukluğu açısından değgerlendirilmesi. Yayımlanmamış Yüksek Lisans Tezi. Gazi Üniversitesi Eğitim Bilimleri Enstitüsü, Ankara.

Büyüköztürk, Ş., Kılıç Çakmak, E., Akgün, Ö. E., Karadeniz, Ş. ve Demirel, F. (2016). Bilimsel araştırma yöntemleri (23. Baskı). Ankara: Pegem Akademi.

Creswell, J. W. (2016).Nitel araştırma yöntemleri (3. bsk). Ankara: Siyasal Kitabevi.

Demir, T. (2013). Yazma becerisine yönelik kazanımların ortaokulda gerçekleşme düzeyi. Okuma Yazma Ĕ̆itimi Araştırmaları, 1(1), 45-56.

Derman, S. (2008). Dil bilgisi öğretiminde metinlerin seçimi üzerine bir araştırma (7. Sınıf). Yayınlanmamış Doktora Tezi, Selçuk Üniversitesi Sosyal Bilimler Enstitüsü,Konya.

Derman S. (2010). Türkçe Öğretmen adaylarının yazılı anlatım becerilerinin incelenmesi. Selçuk Üniversitesi Kemal Akman MYO Tebliğ Günleri, 13-15 Mayıs 2010, Ereğli-Konya.

Eğilmez, N. İ., ve Berber, Z. T. (2017). Beşinci sınıf öğrencilerinin hikâye yazma becerileri. Ana Dili Ĕ̆itimi Dergisi, 5(2), 164-187.

Ekinci Çelikpazu, E. (2006). Erzurum merkez ilçe ilköğretim 6. sinıf öğrencilerinin yazılı anlatım becerileri üzerine bir araştırma. Yayımlanmamış Yüksek Lisans Tezi. Atatürk Üniversitesi Sosyal Bilimler Enstitüsü, Erzurum.

Göçer, A. (2010). Türkçe öğretiminde yazma eğitimi. Journal of International Social Research, 3(12).

Güneş, F.(2013). Yaklaşımlar ve modeller. Ankara: Pegem Akademi.

İnce V. (2006). İlköğretim 3, 4, 5, 6, 7 ve 8. sinı öğrencilerinin yazılı anlatım becerilerinin ölçülmesi ve değerlendirilmesi. Yüksek Lisans Tezi, Muğla Üniversitesi Sosyal Bilimler Enstitüsü Yayımlanmamış, Muğla.

Kan, M. ve Tiryaki, E. (2015). Türkçe öğretmeni adaylarının metin oluşturmadaki sorunları. Mersin Üniversitesi Eğitim Fakültesi Dergisi, 11(2).

Karadağ, Ö. ve Maden, S. (2014). Yazma eğitimi: Kuram, uygulama, ölçme ve değerlendirme. Güzel A., Karatay H.(Ed.), Türkçe Öğretimi El Kitabı, içinde (s.265- 301). Ankara: Pegem Akademi.

Karasar, N.(2002). Bilimsel araştırma yöntemi. Ankara: Nobel Yayın Dağıtım Ltd. Şti.

Karatay, H. (2010).Bağdaşıklık araçlarını kullanma düzeyi ile tutarlı metin yazma arasındaki ilişki.Mustafa Kemal Üniversitesi Sosyal Bilimler Enstitüsü Dergisi, $7(13)$.

MEB (2006a). Illköğretim Türkçe dersi, 6 ,7, 8. sınıflar öğretim programı. Ankara: Millî Eğitim Basımevi. 
MEB (2006b). Dil ve anlatım dersi öğretim programı 9 ,10, 11, 12. sinıflar öğretim programı. Ankara: Millî Eğitim Basımevi.

MEB (2011a). Dil ve anlatım dersi öğretim programı ve kılavuzu. Ankara: MEB Yayınları.

MEB (2011b). Türk Edebiyatı dersi öğretim programı ve kılavuzu. Ankara: MEB Yayınlar1.

MEB. (2018a). Türkçe dersi öğretim programı (ilkokul ve ortaokul 1, 2, 3, 4, 5, 6, 7 ve 8. sinıflar). Ankara: MEB.

MEB. (2018b). Ortä̈ğretim Türk dili ve edebiyatı dersi öğretim programı. Ankara: MEB Yayınları.

Mete, F. (2015). Türkçe öğretmenliği bölümünde yazma eğitimi dersi: Bilme ve uygulama karşılaştırması. Ana Dili Ĕ̆itimi Dergisi, 3(2), 81-91.

Oktay E., (2019). Öğretim kademelerine göre öğrencilerin yazılı anlatım becerilerinin karşılaştırılması. Yayımlanmamış Yüksek Lisans Tezi, Necmettin Erbakan Üniversitesi Eğitim Bilimleri Enstitüsü, Konya.

Özbay, M. (1995). Ankara merkez ortaokullarındaki üçüncü sını öğrencilerin yazılı anlatım becerileri üzerine bir araştırma. Yayımlanmamış Doktora Tezi. Gazi Üniversitesi Eğitim Bilimleri Enstitüsü, Ankara.

Sever, S. (1995). Türkçe öğretiminde tam öğrenme. Ya-pa Yayınları.

Subaşı, M. ve Okumuş, K. (2017). Bir araştırma yöntemi olarak durum çalışması. Atatürk Üniversitesi Sosyal Bilimler Enstitüsü Dergisi, 21(2), 419-426.

Yakıcı, A.,Yücel, M., Yelok, V., S. ve Doğan, M. (2011). Üniversiteler için Türkçe1 yazılı anlatım. Ankara: Gazi.

\section{Kaynakça Bilgisi / Citation Information}

Derman, S. (2020). Farklı öğretim kademelerindeki öğrencilerin deneme türündeki yazılı anlatım becerilerinin değerlendirilmesi. OPUSUluslararası Toplum Araştırmaları Dergisi, 15(26), 4265-4292. DOI: 10.26466/opus.733517 